\title{
Environmental DNA (eDNA) metabarcoding: Diversity study around the Pondok Dadap fish landing station, Malang, Indonesia
}

\author{
SAPTO ANDRIYONO ${ }^{1,2, \boldsymbol{v}}$, MD. JOBAIDUL ALAM ${ }^{1}$, HYUN-WOO KIM ${ }^{1,3}$ \\ ${ }^{1}$ Interdisciplinary Program of Biomedical, Mechanical and Electrical Engineering, Pukyong National University, Busan, 48513, Republic of Korea \\ ${ }^{2}$ Department of Marine, Faculty of Fisheries and Marine Science, Universitas Airlangga. C Campus, Jl. Mulyorejo, Surabaya 60115, East Java, Indonesia. \\ Tel.: +62-31-5911541, `email: sapto.andriyono@ fpk.unair.ac.id \\ ${ }^{3}$ Department of Marine Biology, Pukyong National University, Busan 48513, Republic of Korea
}

Manuscript received: 27 July 2019. Revision accepted: 27 November 2019.

\begin{abstract}
Andriyono S, Jobaidul Alam Md, Kim HW. 2019. Environmental DNA (eDNA) metabarcoding: Diversity study around the Pondok Dadap fish landing station, Malang, Indonesia. Biodiversitas 20: 3772-3781. Molecular identification of species is now fast growing and currently widely applied method in the diversity estimation of aquatic biota; even though morphological identification is still carried out. The molecular approach is beneficial complementing on regular surveys e.g. use of nets, traps, fishing rods, and even with poisons. In this study, the eDNA metabarcoding was applied to water samples around the Pondok Dadap fish landing station, Indonesia to determine the diversity of fish around the waters and also to identify marine fish landed in this area. Molecular identification was carried out on fish samples obtained from the fish market improved GenBank database on COI and ITS. While, seawater samples were carried out by using the next-generation sequencing (NGS) platform to obtain the eDNA metabarcoding data for the first time. Molecular identification obtained 34 species (68 sequences of COI and ITS regions) belonging to 28 genera, 18 families, 4 orders, while the eDNA metabarcoding approach identified 53 marine fish species by using the MiFish pipeline representing 38 genera, 27 families, and 7 orders. From the present study, we can able to estimated fish diversity by eDNA metabarcoding, and this finding will be helpful for baseline data preparation for future effective management of resources in this area.
\end{abstract}

Keywords: Environmental DNA, identification, metabarcoding, molecular

\section{INTRODUCTION}

DNA-base identification is very efficient when a comprehensive reference database available. This method is able to prove in the identification of specimens under specific conditions (Meyer and Paulay 2005). Identification based on DNA barcode has been well-accepted globally due to various advantages, it is very simple and uses a universal tool. It could be utilized in all organisms, both in the fresh samples and processed products (Pepe et al. 2007, Giusti et al. 2017). DNA barcoding was launched since 2005 under iBOL (www.boldsystem.org) even though it was introduced in 2003, which used mtDNA segment on Cytochrome C Oxidase subunit I (COI) as the common region for barcode (Hebert et al. 2003).

This barcoding system uses sequences that have a diversity in the single region of mitochondrial DNA Cytochrome C Subunit I gene (COI) and deposited to the Genbank database as central bioinformatics. Scientists have demonstrated their effectiveness in conducting DNA barcoding in freshwater fish and deep-sea fish (Ward et al. 2005, Lakra et al. 2011).

At present, estimating the presence of species in the waters can be carried out using environmental DNA approaches called eDNA. The extraction and analysis of genetic material are obtained directly from the environment by collecting these living particles as an alternative survey approach to monitoring marine fish (Taberlet et al. 2012). This approach is first carried out on terrestrial sediment samples that can reveal marine mammalian (Foote et al. 2012), bird and plant ecosystems (Willerslev et al. 2003) which are extinct and still exist today. Furthermore, this eDNA metabarcoding approach successfully revealed information on various taxa, various habitats and various weather conditions (Willerslev et al. 2004; AndersonCarpenter et al. 2011; Taberlet et al. 2012). Several reports stated that metabarcoding through eDNA can also be done in biodiversity studies (Karp et al. 1997; de Vargas et al. 2002; Douglas et al. 2012; Thomsen et al. 2012) and suspect invasive biota (Dejean et al. 2012; Takahara et al. 2013), while observing rare biota (Jerde et al. 2011; Wilcox et al. 2013) which is difficult to collect through traditional survey methods. In this study, we conducted a research to estimate the diversity of marine fish and fish caught in Pondok Dadap Malang with the eDNA approach as well as the initial data for further research related to the biodiversity of aquatic biota around the Sempu Island Nature Reserve which located in front of Pondok Dadap fish landing station.

One of the important fisheries commodities in Indonesia is the tuna pelagic fish group which has important economic value and is the mainstay of Indonesian exports. There are at least four species of tuna in Indonesia and one of the landing sites for tuna in East Java is the Pondok Dadap Port, Malang, Indonesia. This southern region of East Java is one of the suppliers of tuna products in East Java and other types of pelagic and nonpelagic fish, although in small quantities. The purpose of 
this study is: (i) to carry out molecular identification of marine fish landed in Pondok Dadap fish landing station due to inexistent clear data about species identification, and (ii) to estimate fish species diversity around the Pondok Dadap fish landing station, which very close to the Sempu Island nature reserve area, through environmental DNA metabarcoding approach based on water sample analysis.

\section{MATERIALS AND METHODS}

\section{Sampling location and sample preparation}

In this research, for environmental DNA metabarcoding study, seawater samples have been collected from five points around the Pondok-Dadap port, Malang, Indonesia ( $\left.8^{\circ} 26^{\prime} 05.65^{\prime \prime S} 112^{\circ} 40^{\prime} 55.31 " \mathrm{E}\right)$, then for barcoding 34 fish specimens were collected in February 2018 for molecular identification. In addition, no specific permission was required for this study, and the individual photograph has been taken by a digital camera. All samples have been collected from the local traditional fish market and those were dead upon the purchasing time and none of the collected specimens were in the endangered category based on the IUCN Red List database.

All specimens for barcoding have been collected based on the morphological characteristics and after collection directly preserved in $90 \%$ ethanol then carried out to the laboratory. The collected samples have been preserved at the Department of Marine, Fisheries and Marine Faculty, Universitas Airlangga, Indonesia following the standard laboratory protocol.

\section{DNA extraction and PCR}

The genomic DNA was extracted from fish samples by using an Accuprep ${ }^{\circledR}$ Genomic DNA Extraction Kit (Bioneer) according to the manufacturer's guidelines. The anal fin $(1 \mathrm{~cm})$ was dissected and mix with $6 \mathrm{x}$ lysis buffer, which was further homogenized by the TissueLyser II (Qiagen). Quantification of purified genomic DNA was performed by nanoDrop (Thermofisher Scientific D1000), aliquoted and stored at the $-70^{\circ} \mathrm{C}$ for further analysis.

Two sets of universal fish primer targeting the Cytochrome c Oxidase I (COI) region, BCL-BCH (Baldwin et al. 2009, Handy et al. 2011) and internal transcribed spacer (ITS) primer sets (Forward F2 5'-CCM YCT AGA GGA GCC TGT YCT RDA A-3'-Reverse R1 5'-CAT GAT GCA AAA GGT AC-3') were used to obtain the partial sequences of each gene, respectively. The ITS region used to improved GenBank database in this region for further our lab works in eDNA metabarcoding. The COI and ITS primer set targeting around 600bp and 700bp sequence, respectively. Both PCR mixture $(20 \mu \mathrm{L})$ contained $11.2 \mu \mathrm{L}$ ultra-pure water, $1 \mu \mathrm{L}$ forward and reverse primer $(0.5 \mu \mathrm{M}), 0.2 \mu \mathrm{L}$ Ex Taq DNA polymerase (TaKaRa, Japan), $2 \mu \mathrm{L}$ 10X ExTag Buffer, $2 \mu \mathrm{L}$ dNTPs (1 $\mu \mathrm{M}$, TaKaRa, Japan), and $2 \mu \mathrm{L}$ genomic DNA as template. The PCR condition (COI and ITS) was carried out under the following setting: $95^{\circ} \mathrm{C}$ for $5 \mathrm{~min}$ in initial denaturation, followed by denaturation at $95^{\circ} \mathrm{C}$ for $30 \mathrm{~s}$ in 40 cycles, $50^{\circ} \mathrm{C}$ for $30 \mathrm{~s}$ in annealing and $72^{\circ} \mathrm{C}$ for $45 \mathrm{~s}$ in extension step, and final extension at $72^{\circ} \mathrm{C}$ for $5 \mathrm{~min}$. The PCR products were purified with AccuPrep ${ }^{\circledR G e l}$ purification kit (Bioneer, Korea). All sequences were aligned and submitted to NCBI GenBank database.

\section{Construction of Library and MiSeq sequencing}

Total genomic DNA was extracted from five filter membrane by Accuprep ${ }^{\circledR}$ Genomic DNA Extraction Kit (Bioneer) according to the manufacturer's manual. Extracted genomic DNA was quantified using Nanodrop spectrophotometer ND1000 (Thermo Scientific, Waltham, MA, USA) and stored at $-80^{\circ} \mathrm{C}$ for further analysis. The Nextera XT index kit (Illumina, USA) was used to construct the library for NGS analysis. The first PCR of MIFISH primer (MIFISH F-R) was performed to connect the adapters. The adapter primers were forward adapter sequences ( 5 '-TCG TCG GCA GCG TCA GAT GTG TAT AAG AGA CAG -3') and reverse adapter sequences (5'GTC TCG TGG GCT CGG AGA TGT GTA TAA GAG ACA G-3') respectively. The final PCR used N7xx and S5xx primer including Illumina Nextera XT indexing primers. Finally, libraries sent for sequencing on Miseq 600-cycle Reagent Kit v3 (Illumina, USA).

The MiFish universal primer sets were used to construct the amplicon libraries of partial 12S rRNA markers (Miya et al. 2015). The total PCR mixture volume was $20 \mu \mathrm{L}$, which contained $1.0 \mu \mathrm{L}$ of MiFish primers ( 5 pmol each), $2.0 \mu \mathrm{L}$ dNTPs $(2.5 \mathrm{mM}), 2.0 \mu \mathrm{L}$ of $10 \mathrm{X}$ EX Taq buffer, 0.6 $\mu \mathrm{L}$ DMSO (3\%), $0.2 \mu \mathrm{L}$ of EX Taq Hot Start (TaKaRa Bio Inc. Japan) and $9.20 \mu \mathrm{L}$ of ultra-pure water. Here, we used 4.0 $\mu \mathrm{L}$ template due to the low genomic DNA concentration that less than $50 \mathrm{ng} / \mu \mathrm{L}$. The PCR setting condition followed the MiFish primer protocol (Miya et al. 2015). The gel electrophoresis (1.5\% agarose) was performed and the expected size $(250 \mathrm{bp} 350 \mathrm{bp})$ was purified by the AccuPrep ${ }^{\circledR}$ Gel Purification Kit (Bioneer, Republic of Korea). Purified amplicons were pass through the second PCR with the corresponding Nextera XT index (Illumina, San Diego, USA) at the end of each amplicon. The total volume for second PCR mixture was $20 \mu \mathrm{L}$ which contain $1 \mu \mathrm{L}$ of a couple of index primers $(10 \mathrm{pmol})$, $0.5 \mu \mathrm{L}$ dNTPs $(10 \mathrm{mM}), 4 \mu \mathrm{L}$ 5X Phusion HF Buffer, 8.3 $\mu \mathrm{L}$ ultrapure water, and $0.2 \mu \mathrm{L}$ Phusion Hot Start Flex DNA polymerase (New England Biolabs, Hitchen, UK), and including $5 \mu \mathrm{L}$ amplicons result from the first PCR. The second PCR setting conditions began with $94^{\circ} \mathrm{C}$ for 5 min for initial denaturation, followed by 15 cycles of $94^{\circ} \mathrm{C}$ for $30 \mathrm{sec}$ for denaturation, $55^{\circ} \mathrm{C}$ for $30-\mathrm{sec}$ annealing, and $72^{\circ} \mathrm{C}$ for $30 \mathrm{sec}$ for extension, and an additional $5 \mathrm{~min}$ at 72 ${ }^{\circ} \mathrm{C}$ for the final extension. The gel electrophoresis and purification were performed similar to the first PCR process, then PCR products with the expected sizes were analyzed by qubit dsDNAHS Assay Kit (Invitrogen, Carlsbad, CA, USA) for quantification of amplicons concentration. The next-generation sequencing was applied using MiSeq platform (2 X $300 \mathrm{bp}$ ).

Before uploaded NGS raw data to the MiFish pipeline, Phyton27 (an open-source software) was used to make pairing of both reverse and forward sequences with the specific script (Zhang 2015). In MiFish pipeline, the raw 
reads by MiSeq sequencing run FASTQC, which will trimming for low-quality tail of reads $(\mathrm{QV} \leq 20)$, assembled paired-end reads and followed by removed $\mathrm{N}$ containing reads, filtered reads by length ( $\sim 229 \mathrm{bp})$, run Usearch ( 0.99 for clustering of identity, and 10 for minimum read size for filtering), BLASTN based on GenBank database, and then created multi-FASTA files for each samples. The next step is run MAFFT, run Morphy for each sample, run Morphy against merged samples, run BLASTN, and finalization of the last process by BLASTN. The total sequences stipulated to operational taxonomic units (OTUs) by compared to the GenBank database, then the sequences were ascertained as 'species', 'genus', and 'unknown' level if the sequence identity more than or similar to $99 \%, 97-98 \%$, and less than $97 \%$, respectively. The distribution for each species was confirmed by FishBase (http://www.fishbase.org/) then taxonomic nomenclature was confirmed under World Register of Marine Species WORMS through online system (http://www.marinespecies.org/).

\section{Data analysis}

Tables and figures of data were performed by Excel 2010, similarity and biodiversity analysis using Primer v7 program. The data on the common local name of fish landed in Pondok Dadap fish station was provided by the East Java Province's Office of Marine and Fisheries, and also previous study using Underwater Visual Census (UVC) around Sendang Biru, Malang by (Luthfi et al. 2016). Phylogenetic tree constructed by Mega7 (Kumar et al. 2016) using Neighbor-Joining algorithm both eDNA sequences results.

\section{RESULTS AND DISCUSSION}

\section{Species identification}

A total of 34 (COI and ITS) sequences generated from 34 fish samples representing 28 genera, 18 families, 4 order (Table 1). The Sanger dideoxy sequencing (direct sequencing) of the partial COI and ITS gene regions produced sequences of more than 600 nucleotide base pairs per taxon $607 \mathrm{bp}$ for COI and $629 \mathrm{bp}$ for ITS). The COI gene region is the universal gene for species barcoding (Hubert and Hanner 2015), the ITS region is new segment for species identification which potential for environmental DNA metabarcoding in our future laboratory experiments. All sequences obtained have been convinced that no stop codons were found, deletion and insertion were observed.

\section{The eDNA Metabarcoding}

The eDNA metabarcoding by using the MiFish pipeline (Miya et al. 2015, Sato et al. 2018), we were able to identify 53 marine fish species (sequence identity 99$100 \%$ ) representing 38 genera, 27 families, 7 order. Total reads from the MiFish pipeline by using eDNA samples were 151,465 (Table 2). Here, the Atlantic Bluefin tuna Thunnus thynnus is dominated $(71.28 \%)$, followed by Bigeye tuna, Thunnus obesus (12.12\%) and Skipjack tuna
Katsuwonus pelamis (7.08\%). Atlantic Bluefin tuna Thunnus thynnus not Inhabitat in Indian Ocean and Pacific ocean but detected by eDNA metabarcoding in this research. There are two reason may happen due to some samples biased (Sato et al. 2017) and weakness of PCR primer during library construction which not suitable for tuna fish species. As explained in the article on MiFish primer that this primer has limitation to distinguishing tuna species (Miya et al. 2015), further research is needed in this regard. Based on phylogenetic reconstruction show that some tuna species in one line with other Scombridae species. The species of Thunnus obesus, Thunnus maccoyii, and also Thunnus thynnus clustered in similar lines by zeno in genetic distance and unable distinguished within this those tuna species. Then another tuna species, Thunnus alalunga and Thunnus orientalis, have low in genetic distance range 0.007-0.014 (Figure 1).

\section{Discussion \\ Species identification}

Molecular identification provides an effective tool for accurate species identification and is widely applied, although there may be limitations due to incomplete database (Teletchea 2009). At present, the application of metabarcoding is also one of the most efficient methods for estimating species that live in a habitat without having to conduct costly and consuming surveys (Rees et al. 2014, Roussel et al. 2015, Piggott 2016, Foote et al. 2012). The challenges remain for application of metabarcoding needs concern on the sensitivity of this method to non-target DNA contamination, primer biases, sequencing artifacts, species misidentification, and also sampling biases (Sato et al. 2017). This method also requires adequate equipment support and bioinformatic data processing.

In this report, we have collected fish sold at the Pondok Dadap port and at the same time deposit the molecular data of Indonesian fish in the GenBank database as a new sequence. The molecular identification method in the COI region has become very common (Matzen da Silva et al. 2011; Aziz et al. 2016; Udayasuriyan and Kalpana 2018). Here, we also used the ITS region beside the COI region. ITS region has not been widely used in molecular identification, since COI is most popular gene marker (Avise 2012). ITS region generally has been used to identify types of fungi (Das and Deb, 2015 Badotti et al. 2017), but this time, the accuracy of identification in vertebrates also produced quite good results. Out of the 34 species that were successfully identified, 13 species did not immediately get results at the species level due to the limitations of the information in the NCBI GenBank database. Unlike the COI region, which is more than enough related to the vertebrate database, so that in this study, the results of identification with the COI region became confirmation data in the ITS region. In this study, the 13 sequences generated were new entries in the GenBank database in the ITS region. Furthermore, in further research, the ITS region can be used in identification at the species level. 


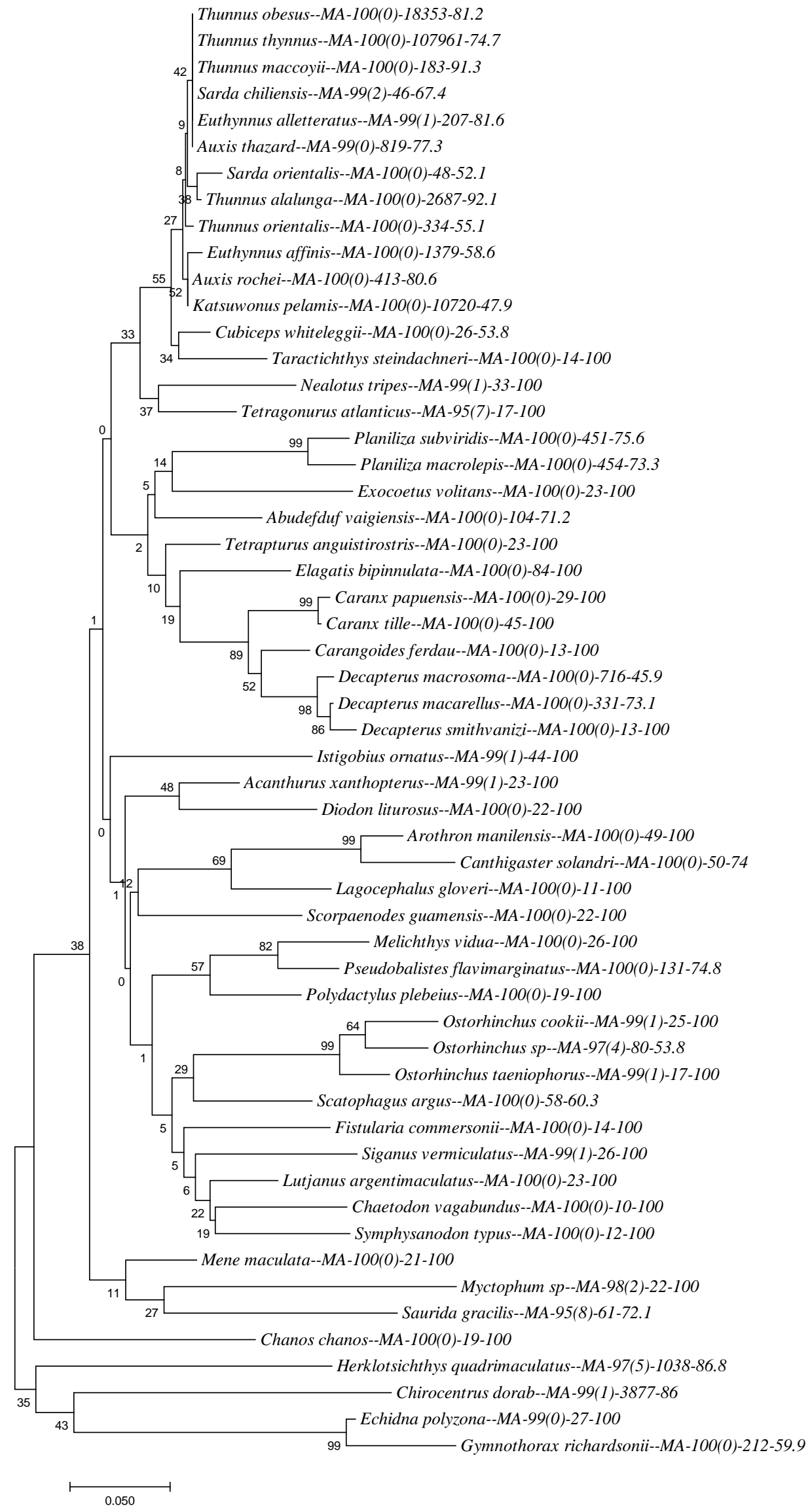

Figure 1. Neighbor-Joining method of phylogenetic tree analysis for sequences generated by eDNA metabarcoding 

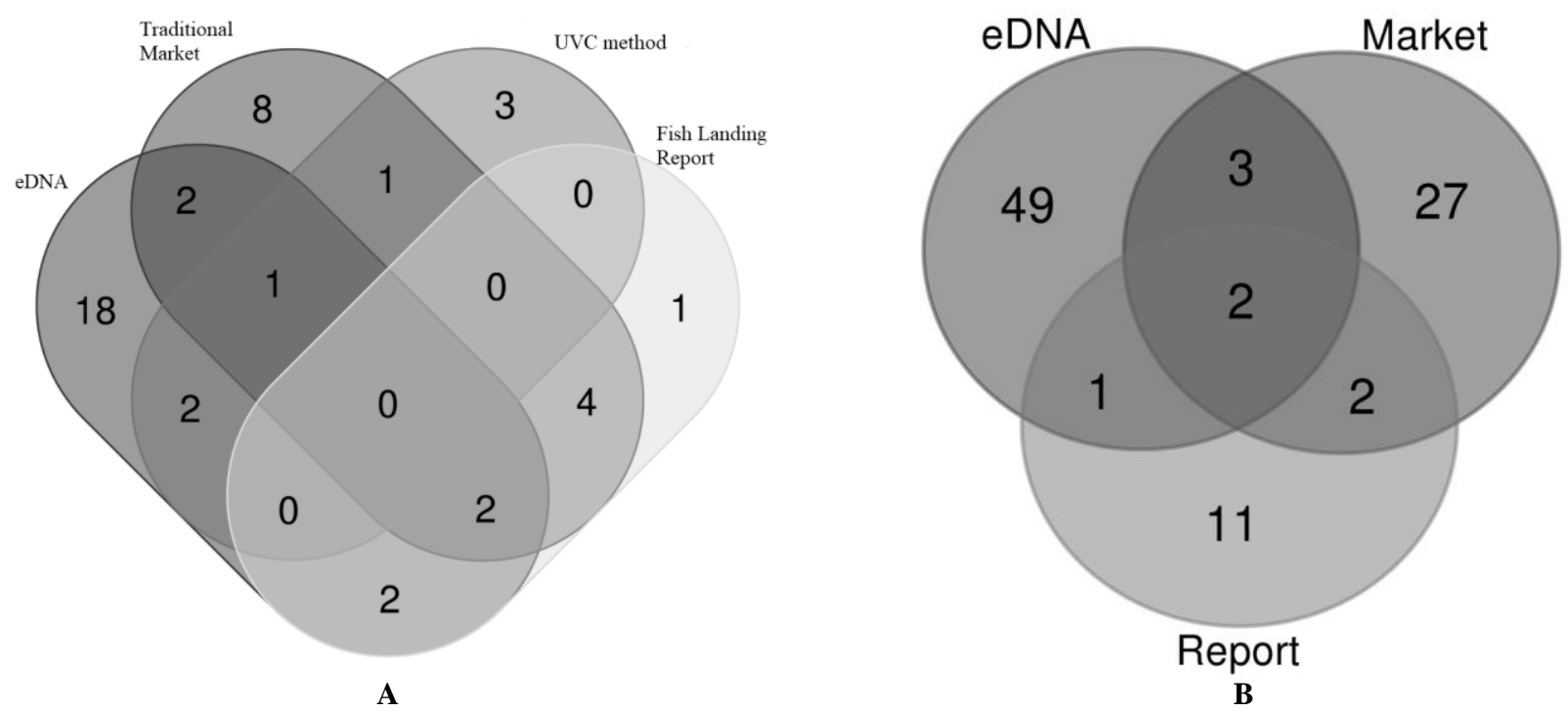

Figure 2. Venn diagrams on fish species data collection methods at the Family level (A: 4 methods) and at species level (B: 3 methods).

The eDNA metabarcoding analysis

In this study, we demonstrated the efficiency of eDNA applications around the fish landing station in Pondok Dadap Malang and at the same time carried out molecular identification of marine fish species sold by traditional fishermen in locations not far from the port. Overlay results from species identified between eDNA metabarcoding and fish sold in conventional markets show only five families were found through both approaches.

The effectiveness of eDNA metabarcoding has been successfully proven and supported in studies on numerous aquatic biota (Pilliod et al. 2013, Rees et al. 2014) that are difficult to collect and endangered (Thomsen et al. 2012, Laramie et al. 2015, Ikeda et al. 2016), as well as endemic (Jerde et al. 2011), and invasive species (Dejean et al. 2012, Takahara et al. 2013). Furthermore, eDNA can provide an overview of biodiversity (Thomsen et al. 2012) in the region that is related to periodic studies and compare it with diversity in the other areas. This method is considered entirely environment-friendly, reduces the survey costs which could be quite high, requiring a considerable amount of equipment, or in other words, this method is very cost-effective (Smart et al. 2016).

Here, we also overlayed the results with previous studies that carried out underwater surveys in the waters around the port and Sempu Island (Luthfi et al. 2016). This reported that only gathered three families marine fish which included in this eDNA metabarcoding list result. The advantages of eDNA metabarcoding complement to other methods, most species detected and had similarity values ranging from $95-100 \%$, with a significant proportion of $72.41 \%$ and $1.72 \%$ having $100 \%$ and $99 \%$ identities with the GenBank voucher sequences. This result is in line with previous studies, comparing traditional survey methods (underwater visual census and trawling) with eDNA sampling, which showed that latter superiority in detecting higher number of species in water (Yamamoto et al. 2017).

A previous underwater visual census (UVC) method only found seven families of reef fish which did not coincide with the capture fisheries results reported by the Pondok Dadap fish landing station office Malang (Luthfi et al. 2016). The Pondok Dadap fish landing office only reported the specific on pelagic fish groups especially reporting catches of tuna fish (Hermawan 2006, Firdaus and Witomo 2014). Current study, we overly eDNA metabarcoding result, barcoding species from fish market, fish list from Pondok Dadap fish landing station, and previous scientific report using UVC method. The Venn diagram only able overlayed until family level (Figure 2A), and remaining is overlayed between three data until species level (Figure 2B). This report complements each other as baseline data of marine fish diversity around Pondok Dadap fish landing station. The eDNA metabarcoding results show that they were unable to detect all fish which was reported by Pondok Dadap fish landing station office due to two possibilities. First, the official report from fish landing station only focused on certain commodities (Scombridae) and they use the local name without confirmation of scientific name of each species. Here, we try to convert the local name to scientific name base on the other scientific reports (Faizah and Aisayah 2017). Secondly, almost all small-size tuna fish species at fish landing station reports were categorized as baby tuna and bring possibility of mixed within tuna species. 
Table 1. List of marine fish species identified by COI and ITS gene region. Grey color at ITS region shown that new entry for GenBank database

\begin{tabular}{|c|c|c|c|c|c|c|c|}
\hline \multirow{2}{*}{ Order } & \multirow{2}{*}{ Family } & \multirow{2}{*}{ Species } & \multirow{2}{*}{ Common name } & \multirow{2}{*}{ Habitat distribution } & \multirow{2}{*}{$\begin{array}{c}\text { GenBank accession } \\
\text { no. for confirmation }\end{array}$} & \multicolumn{2}{|c|}{ GenBank accession no. } \\
\hline & & & & & & COI gene & ITS gene \\
\hline \multirow[t]{29}{*}{ Perciformes } & Serranidae & Cephalopholis sonnerati & Tomato hind & Indo Pacific & KU668634 & MH085806 & MH190804 \\
\hline & Drepanidae & Drepane punctata & Spotted sickle fish & Indo-West Pacific & KM273123 & MH085841 & MH085677 \\
\hline & Acanthuridae & Acanthurus bariene & Black-spot surgeonfish & Indo-West Pacific & KF009560 & MH085850 & MH085682 \\
\hline & \multirow[t]{2}{*}{ Pomacanthidae } & Pomacanthus annularis & Bluering angelfish & Indo-West Pacific & FJ583876 & MH085785 & MH085679 \\
\hline & & Pomacanthus semicirculatus & Semicircle angelfish & Indo-West Pacific & FJ583886 & MH085786 & МH085680 \\
\hline & Sphyraenidae & Sphyraena putnamae & Sawtooth barracuda & Indo-West Pacific & КC970510 & MH085781 & MH085673 \\
\hline & \multirow[t]{2}{*}{ Balistidae } & Sufflamen chrysopterum & Halfmoon triggerfish & Indo-West Pacific & FJ584131 & MH085791 & MH190805 \\
\hline & & Canthidermis maculata & Rough triggerfish & Western Pacific & AP009206 & MH085790 & MH085689 \\
\hline & \multirow[t]{5}{*}{ Scombridae } & Scomber australasicus & Blue mackerel & Indo-West Pacific & KX781882 & MH085913 & MH085694 \\
\hline & & Sarda orientalis & Striped bonito & Indo Pacific & KX768133 & MH085916 & MH085692 \\
\hline & & Euthynnus affinis & Kawakawa & Indo-West Pacific & KX768124 & MH085918 & MH085691 \\
\hline & & Katsuwonus pelamis & Skipjack tuna & Worldwide & KF597042 & MH085920 & МH085683 \\
\hline & & Auxis thazard & Frigate tuna & $\begin{array}{l}\text { Atlantic, Indian and Pacific } \\
\text { (Western central) }\end{array}$ & KM055419 & MH190813 & MH190806 \\
\hline & Priacanthidae & Priacanthus tayenus & Purple-spotted bigeye & Indo-West Pacific & KT985639 & MH085759 & MH085676 \\
\hline & \multirow{5}{*}{ Lutjanidae } & Lutjanus erythropterus & Crimson snapper & Indo-West Pacific & KР939271 & MH085859 & MH085669 \\
\hline & & Lutjanus gibbus & Humpback red snapper & Indo Pacific & MF409615 & MH190812 & MH085686 \\
\hline & & Lutjanus bengalensis & Bengal snapper & Indo-West Pacific & FJ171339 & MH085862 & MH085668 \\
\hline & & Lutjanus notatus & Blue striped snapper & Western Indian Ocean & JF483844 & MH190812 & MH085688 \\
\hline & & Scolopsis ciliata & Saw-jawed monocle bream & Indo-West Pacific & KY362946 & MH085856 & MH085685 \\
\hline & \multirow[t]{5}{*}{ Carangidae } & Atule mate & Yellowtail scad & Indo Pacific & KU170601 & MH085895 & MH085672 \\
\hline & & Decapterus macarellus & Mackerel scad & Western Atlantic, Global & KY371379 & MH085882 & MH085695 \\
\hline & & Decapterus maruadsi & Japanese scad & Indo-West Pacific & KX610924 & MH085880 & MH085675 \\
\hline & & Alectis indicus & Indian threadfish & Indo Pacific & NC037050 & MH085892 & MH085678 \\
\hline & & Megalaspis cordyla & Torpedo scad & Indo-West Pacific & KM522836 & - & - \\
\hline & Scaridae & Scarus niger & Dusky parrotfish & Indo Pacific & KP194654 & MH085810 & MH085681 \\
\hline & Nomeidae & Cubiceps pauciradiatus & Bigeye cigarfish & Atlantic, Indian, and Pacific & MF956610 & MH190814 & MH085697 \\
\hline & Coryphaenidae & Coryphaena hippurus & Common dolphinfish & Atlantic, Indian, and Pacific & AP009206 & MH085771 & МH085696 \\
\hline & Pinguipedidae & Parapercis hexophtalma & Speckled sand perch & Indo Pacific & MF123971 & MH085798 & MH085687 \\
\hline & Leiognathidae & Photopectoralis bindus & Orangefin ponyfish & Indo-West Pacific & KY849543 & MH085768 & MH085674 \\
\hline \multirow[t]{3}{*}{ Beryciformes } & \multirow[t]{3}{*}{ Holocentridae } & Sargocentron diadema & Crown squirrelfish & Indo Pacific & JF494418 & MH085901 & MH085645 \\
\hline & & Myripristis berndti & Blotch eye soldierfish & Indo-Pacific and Eastern Pacific & AP002940 & MH085854 & MH085670 \\
\hline & & Myripristis adusta & Shadowfin soldierfish & Indo-Pacific & KU943296 & MH190811 & MH085671 \\
\hline Siluriformes & Ariidae & Netuma thalassina & Giant catfish & Indo-West Pacific & KC569771 & MH085824 & MH085690 \\
\hline Beloniformes & Belonidae & Tylosurus acus & Agujon needlefish & Western Atlantic & КC970513 & MH085783 & МH085684 \\
\hline
\end{tabular}


Table 2. List of marine fish species detected by eDNA metabarcoding approach including read number and read proportion

\begin{tabular}{|c|c|c|c|c|c|c|}
\hline Order & Family & Species name & Distribution & $\begin{array}{l}\text { Identity } \\
(\%)\end{array}$ & $\begin{array}{l}\text { Total } \\
\text { read }\end{array}$ & $\begin{array}{l}\text { Read proportion } \\
(\%)\end{array}$ \\
\hline \multirow[t]{2}{*}{ Anguilliformes } & Muraenidae & Echidna polvzona & Indo-Pacific & 99 & 27 & 100 \\
\hline & & Gymnothorax richardsonii & Indo-Pacific & 100 & 212 & 59.9 \\
\hline Aulopiformes & Synodontidae & Saurida gracilis (unknown) & Indo-Pacific & 95 & 61 & 72.1 \\
\hline Beloniformes & Exocoetidae & Exocoetus volitans & Widespread in tropical and subtropical & 100 & 23 & 100 \\
\hline \multirow[t]{2}{*}{ Clupeiformes } & Clupeidae & Herklotsichthys sp. & Indo-Pacific & 97 & 1038 & 86.8 \\
\hline & Chirocentridae & Chirocentrus dorab & Indo-Pacific & 99 & 3877 & 86 \\
\hline Gonorynchiformes & Chanidae & Chanos chanos & Indo-Pacific & 100 & 19 & 100 \\
\hline \multirow[t]{2}{*}{ Mugiliformes } & Mugilidae & Planiliza macrolepis & Indo-Pacific & 100 & 454 & 73.3 \\
\hline & & Planiliza subviridis & Indo-Pacific & 100 & 451 & 75.6 \\
\hline Myctophiformes & Myctophidae & Myctophum sp. & Atlantic, Indian and Pacific & 98 & 22 & 100 \\
\hline \multirow[t]{25}{*}{ Perciformes } & Tetragonuridae & Tetragonurus atlanticus (unknown) & Atlantic, Indian and Pacific & 95 & 17 & 100 \\
\hline & Apogonidae & Ostorhinchus sp. & Indo-Pacific & 97 & 80 & 53.8 \\
\hline & Acanthuridae & Acanthurus xanthopterus & Indo-Pacific & 99 & 23 & 100 \\
\hline & Gobiidae & Istigobius ornatus & Indo-Pacific & 99 & 44 & 100 \\
\hline & Gempylidae & Nealotus tripes & Atlantic, Indian and Pacific & 99 & 33 & 100 \\
\hline & Apogonidae & Ostorhinchus cookii & Indo-Pacific & 99 & 25 & 100 \\
\hline & & Ostorhinchus taeniophorus & Indo-Pacific & 99 & 17 & 100 \\
\hline & Siganidae & Siganus vermiculatus & Indo-West Pacific & 99 & 26 & 100 \\
\hline & Pomacentridae & Abudefduf vaigiensis & Indo-Pacific & 100 & 104 & 71.2 \\
\hline & Chaetodontidae & Chaetodon vagabundus & Indo-Pacific & 100 & 10 & 100 \\
\hline & Nomeidae & Cubiceps whiteleggii & Indo-West Pacific & 100 & 26 & 53.8 \\
\hline & Carangidae & Carangoides ferdau & Indo-Pacific & 100 & 13 & 100 \\
\hline & & Caranx papuensis & Indo-Pacific & 100 & 29 & 100 \\
\hline & & Caranx tille & Indo-West Pacific & 100 & 45 & 100 \\
\hline & & Decapterus macarellus & Circumglobal & 100 & 331 & 73.1 \\
\hline & & Decapterus macrosoma & Indo-Pacific and Southeast Atlantic & 100 & 716 & 45.9 \\
\hline & & Decapterus smithvanizi & - & 100 & 13 & 100 \\
\hline & & Elagatis bipinnulata & Indo-Pacific & 100 & 84 & 100 \\
\hline & Lutjanidae & Lutjanus argentimaculatus & Indo-West Pacific & 100 & 23 & 100 \\
\hline & Menidae & Mene maculata & Indo-West Pacific & 100 & 21 & 100 \\
\hline & Polynemidae & Polydactylus plebeius & Indo-Pacific & 100 & 19 & 100 \\
\hline & Scatophagidae & Scatophagus argus & Indo-Pacific & 100 & 58 & 60.3 \\
\hline & Symphysanodontidae & Symphysanodon typus & Pacific Ocean & 100 & 12 & 100 \\
\hline & Bramidae & Taractichthys steindachneri & Indo-Pacific and Eastern Central Pacific & 100 & 14 & 100 \\
\hline & Istiophoridae & Tetrapturus anguistirostris & Indian and Pacific & 100 & 23 & 100 \\
\hline
\end{tabular}




\begin{tabular}{|c|c|c|c|c|c|c|}
\hline & Scombridae & Auxis thazard & Atlantic, Indian and Pacific & 99 & 819 & 77.3 \\
\hline & & Euthynnus alletteratus & Atlantic ocean & 99 & 207 & 81.6 \\
\hline & & Auxis rochei & Atlantic, Indian and Pacific & 100 & 413 & 80.6 \\
\hline & & Euthynnus affinis & Indo-West Pacific & 100 & 1379 & 58.6 \\
\hline & & Katsuwonus pelamis & Cosmopolitan in tropical and warm-temperate water & 100 & 10720 & 47.9 \\
\hline & & Sarda chiliensis & Southeast Pacific & 99 & 46 & 67.4 \\
\hline & & Sarda orientalis & Indo-Pacific & 100 & 48 & 52.1 \\
\hline & & Thunnus alalunga & Cosmopolitan in tropical and temperate waters & 100 & 2687 & 92.1 \\
\hline & & Thunnus maccoyii & Atlantic, Indian and Pacific & 100 & 183 & 91.3 \\
\hline & & Thunnus obesus & Atlantic, Indian and Pacific & 100 & 18353 & 81.2 \\
\hline & & Thunnus orientalis & North to South Pacific & 100 & 334 & 55.1 \\
\hline & & Thunnus thynnus & Western and Eastern Atlantic & 100 & 107961 & 74.7 \\
\hline Scorpaeniformes & Scorpaenidae & Scorpaenodes guamensis & Indo-Pacific & 100 & 22 & 100 \\
\hline Syngnathiformes & Fistulariidae & Fistularia commersonii & Indo-Pacific & 100 & 14 & 100 \\
\hline Tetraodontiformes & Tetraodontidae & Arothron manilensis & Western Pacific & 100 & 49 & 100 \\
\hline & & Lagocephalus gloveri & Indo-West Pacific & 100 & 11 & 100 \\
\hline & & Canthigaster solandri & Indo-Pacific & 100 & 50 & 74 \\
\hline & Diodontidae & Diodon liturosus & Indo-Pacific & 100 & 22 & 100 \\
\hline & Balistidae & Melichthys vidua & Indo-Pacific & 100 & 26 & 100 \\
\hline & & Pseudobalistes flavimarginatus & Indo-Pacific & 100 & 131 & 74.8 \\
\hline
\end{tabular}


The Pondok Dadap fish landing station reported only noted for the pelagic fish caught from the Indian Ocean waters (includes the South Nusa Tenggara, the Sawu Sea, and the Western Timor Sea (Firdaus and Witomo 2014), and remaining as non-pelagic species from around Sempu Island. Here, the eDNA metabarcoding method was able to detect five tuna species (Thunnus alalunga, T. obesus, $T$. maccoyii, $T$. orientalis, and $T$. thynnus), two species bonito (Sarda chiliensis and Sarda orientalis), and two species little tunny (Euthynnus alletteratus and Euthynnus affinis), which not reported clearly in fish landing report (Table 2). Almost all Scombridae species which have been identified on the eDNA metabarcoding by DNA contamination from those fish during landing process at Pondok Dadap fish landing station. The Atlantic bluefin tuna was identified by eDNA metabarcoding which biased of this method due to the MiFish primer which developed can not able distinguished the tuna species (Miya et al. 2015, Sato et al. 2018).

The results of these studies of fish samples from traditional markets and eDNA metabarcoding, the most fish groups obtained are the Perciformes order (Figure 3). In traditional markets, the proportion of Perciformes group was $85.29 \%$, which was higher than result from eDNA metabarcoding which was $67.27 \%$. These fish belong to the Scombridae, Lutjanidae and Carangidae families. Perciformes group is an economically important fish such as Thunnus albacores, Katsuwonus pelamis, Euthynnus sp, Istiophorus sp., and Scomberomerus sp. (Firdaus and Witomo 2014). However, the fish group in the Scombridae fish family is at the top of the list of fish caught reported by the Pondok Dadap fish landing station with the highest economic value, especially for tuna fish species (Abdullah and Rehbein 2014).

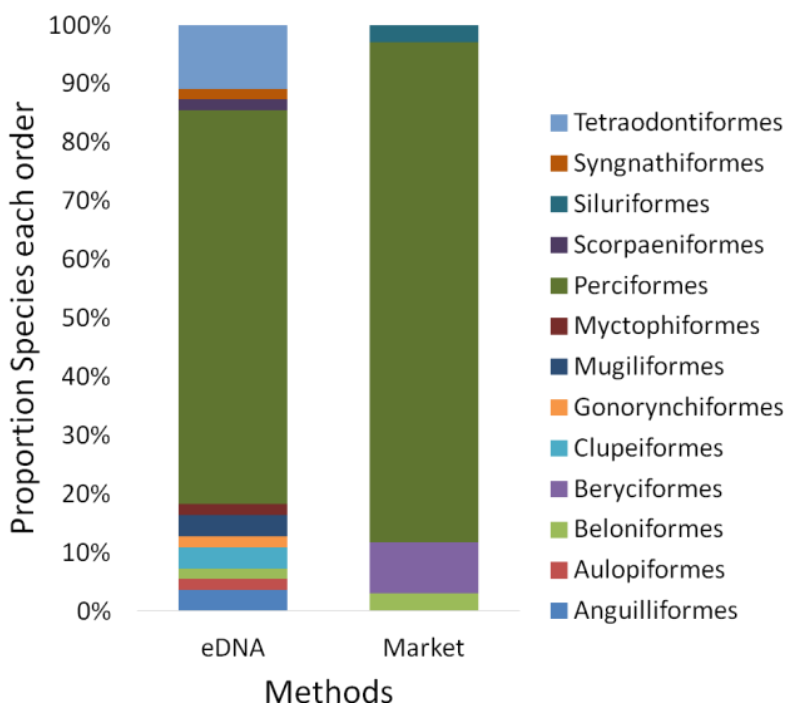

Figure 3. Comparison of species proportion each order between eDNA metabarcoding around Pondok Dadap fish landing station and fishes species sold at Sendang Biru fish market Malang, Indonesia
In the list of all species of marine fish, Perciformes are the most consumed fish and are abundant in shallow waters and pelagic fish that have high economic value (Jaafar et al. 2012). This catch is a source of food and protein for people in coastal areas of developing countries such as in Indonesia which is still very dependent on the availability of natural resources (Ferrol-Schulte et al. 2015). By understanding the potential and diversity of fish in the Pondok Dadap area of Malang, these natural resources must be appropriately managed and adequately for a better future.

In conclusion, the eDNA metabarcoding has successfully identified tropical fish in Malang Indonesia with the MiFish pipeline. This approach with eDNA provides a better picture of the types of fish that are likely to have habitats around the Pondok Dadap fish landing station. This information also complements data on reef fish species using UVC. In addition, this study also succeeded in documenting genetic information from 34 marine fish species in the COI and ITS gene regions, and 13 of them were the first entries for the ITS segment in the NCBI GenBank database. The eDNA approach is carried out quite efficiently in gathering diversity data and becoming a method that complements the results of traditional survey methods. Periodic monitoring and investigation are needed to manage fisheries resources around Pondok Dadap fish landing station. This management can be done by conducting regular surveys and collaborating between all stakeholders to preserve fisheries resources for a better future.

\section{ACKNOWLEDGEMENTS}

This work was supported by an educational grant from the LPDP BUDI-LN batch I 2016 and molecular physiology, Pukyong National University, Korea.

\section{REFERENCES}

Abdullah A, Rehbein H. 2014. Authentication of raw and processed tuna from Indonesian markets using DNA barcoding, nuclear gene, and character-based approach. J Euro Food Res Tech 239: 695-706.

Anderson-Carpenter LL, McLachlan JS, Jacson ST, Kuch M., Lumibao, CY, Poinar HN. 2011. Ancient DNA from lake sediments: bridging the gap between paleoecology and genetics. BMC Evol Biol 11: 3045.

Avise JC. 2012. Molecular Markers, Natural History and Evolution, Springer Science \& Business Media, New York.

Aziz NMA, Esa Y, Arshad A. 2016. DNA barcoding and phylogenetic analysis of Malaysian groupers (Subfamily: Epinephelinae) using mitochondrial Cytochrome c oxidase I (COI) gene. J Enviro Biol 37: 725-733.

Badotti F, De Oliveira FS, Garcia CF, Vaz ABM, Fonseca PLC, Nahum, LA, Oliveira G, Goes-Neto A. 2017. Effectiveness of ITS and subregions as DNA barcode markers for the identification of Basidiomycota (Fungi). BMC Microbiol 17: 42.

Baldwin CC, Mounts JH, Smith DG, Weigt LA. 2009. Genetic identification and color descriptions of early life-history stages of Belizean Phaeoptyx and Astrapogon (Teleostei: Apogonidae) with comments on identification of adult Phaeoptyx. Zootaxa 2008: 1-22.

Das S, Deb B. 2015. DNA barcoding of fungi using Ribosomal ITS Marker for genetic diversity analysis: a review. Intl J Pure Appl Biosci 3: 160-167. 
De Vargas C, Bonzon M, Rees NW, Pawlowski J, Zaninetti L. 2002. A molecular approach to biodiversity and biogeography in the planktonic foraminifer Globigerinella siphonifera (d'Orbigny). Mar Micropaleontol 45: 101-116.

Dejean T, Valentini A, Miquel C, Taberlet P, Bellemain E, Miaud C. 2012. Improved detection of an alien invasive species through environmental DNA barcoding: the example of the American bullfrog Lithobates catesbeianus. J App Ecol 49: 953-959.

Douglas WY, Ji Y, Emerson BC, Wang X, Ye C, Yang C, Ding Z. 2012. Biodiversity soup: metabarcoding of arthropods for rapid biodiversity assessment and biomonitoring. Methods Ecol Evol 3: 613-623.

Faizah R, Aisayah A. 2017. Komposisi Jenis dan Distribusi Ukuran Ikan Pelagis Besar Hasil Tangkapan Pancing Ulur di Sendang Biru, Jawa Timur. J Bawal WRPT 3: 377-385. [Indonesian]

Ferrol-Schulte D, Gorris P, Baitoningsih W, Adhuri DS, Ferse SC. 2015. Coastal livelihood vulnerability to marine resource degradation: A review of the Indonesian national coastal and marine policy framework. Mar Pol 52: 163-171.

Firdaus M, Witomo CM. 2014. Analisis tingkat kesejahteraan dan ketimpangan pendapatan rumah tangga nelayan pelagis besar di Sendang Biru, Kabupaten Malang, Jawa Timur. J Sosek Kelautan dan Perikanan 9: 155-168. [Indonesian]

Foote AD, Thomsen PF, Sveegaard S, Wahlberg M, Kielgast J, Kyhn LA, Salling AB, Galatius A, Orlando L, Gilbert MTP. 2012. Investigating the potential use of environmental DNA (eDNA) for genetic monitoring of marine mammals. PloS One 7: e41781.

Giusti A, Armani A, Sotelo CG. 2017. Advances in the analysis of complex food matrices: Species identification in surimi-based products using Next Generation Sequencing technologies. PloS One 12: $1-18$.

Handy SM, Deeds JR, Ivanova NV, Hebert PD, Hanner RH, Ormos A, Weigt LA, Moore MM, Yancy HF. 2011. A single-laboratory validated method for the generation of DNA barcodes for the identification of fish for regulatory compliance. J AOAC Intl 94: 201 210.

Hebert PD, Cywinska A, Ball SL, Dewaard JR. 2003. Biological identifications through DNA barcodes. Proc R Soc London B Biol Sci 270: 313-321.

Hermawan D. 2006. The prospective of Sendang Biru coastal zone development for integrated fisheries industry. J. Prot.13 (2): 203-210.

Hubert N, Hanner R. 2015. DNA barcoding, species delineation and taxonomy: a historical perspective. DNA barcodes, 3, 44-58.

Ikeda K, Doi H, Tanaka K, Kawai T, Negishi JN. 2016. Using environmental DNA to detect an endangered crayfish Cambaroides japonicus in streams. Con Gen Res 8: 231-234.

Jaafar TNAM, Taylor MI, Nor SAM, De Bruyn M, Carvalho GR. 2012. DNA barcoding reveals cryptic diversity within commercially exploited Indo-Malay Carangidae (Teleostei: Perciformes). PLoS One 7: e49623.

Jerde CL, Mahon AR, Chadderton WL, Lodge DM. 2011. "Sight-unseen" detection of rare aquatic species using environmental DNA. Con Letl 4: $150-157$.

Karp A, Edwards KJ, Bruford M, Funk S, Vosman B, Morgante M, Seberg O, Kremer A, Boursot P, Arctander P. 1997. Molecula technologies for biodiversity evaluation: opportunities and challenges. Nature biotech, 15: 625 .

Kumar S, Stecher G, Tamura K. 2016. MEGA7: molecular evolutionary genetics analysis version 7.0 for bigger datasets. Mol Biol Evol 33: $1870-1874$

Lakra W, Verma M, Goswami M, Lal KK, Mohindra V, Punia P, Gopalakrishnan A, Singh K, Ward RD, Hebert P. 2011. DNA barcoding Indian marine fishes. Mol Ecol Res 11: 60-71.

Laramie MB, Pilliod DS, Goldberg CS. 2015. Characterizing the distribution of an endangered salmonid using environmental DNA analysis. Biol Con 183: 29-37.

Luthfi OM, Pujarahayu P, Wahyudiarto A, Fakri SR, Sofyan M, Ramadhan F, Murian S, Tovani I, Mahmud M, Adi D. 2016. Biodiversitas dan populasi ikan karang di perairan Selat Sempu Sendang Biru Kabupaten Malang Jawa Timur. J Kelautan: Indon J Mar Sci Tech 9: 43-49.
Matzen Da Silva J, Creer S, Dos Santos A, Costa A, Cunha M. 2011. Systematic and evolutionary insights derived from mtDNA COI Barcode. PLoS One 6 (5): e19449.

Meyer CP, Paulay G. 2005. DNA barcoding: error rates based on comprehensive sampling. PLoS Biol 3: e422.

Miya M, Sato Y, Fukunaga T, Sado T, Poulsen JY, Sato K, Minamoto T, Yamamoto S, Yamanaka H, Araki H. 2015. MiFish, a set of universal PCR primers for metabarcoding environmental DNA from fishes: detection of more than 230 subtropical marine species. Royal Soc Open Sci 2: 150088 .

Pepe T, Trotta M, Di Marco I, Anastasio A, Bautista JM, Cortesi ML. 2007. Fish species identification in surimi-based products. J Agric Food Chem 55: 3681-3685.

Piggott MP. 2016. Evaluating the effects of laboratory protocols on eDNA detection probability for an endangered freshwater fish. Ecol Evol 6: 2739-2750.

Pilliod DS, Goldberg CS, Laramie MB, Waits LP. 2013. Application of environmental DNA for inventory and monitoring of aquatic species, US Department of the Interior, US Geological Survey, Washington, DC.

Rees HC, Maddison BC, Middleditch DJ, Patmore JR, Gough KC. 2014. The detection of aquatic animal species using environmental DNA-a review of eDNA as a survey tool in ecology. J Appl Ecol 51: 14501459

Roussel JM, Paillisson JM, Treguier A, Petit E. 2015. The downside of eDNA as a survey tool in water bodies. J App Ecol 52: 823-826.

Sato H, Sogo Y, Doi H, Yamanaka H. 2017. Usefulness and limitations of sample pooling for environmental DNA metabarcoding of freshwater fish communities. Sci Rep 7: 14860.

Sato Y, Miya M, Fukunaga T, Sado T, Iwasaki W. 2018. MitoFish and MiFish pipeline: a mitochondrial genome database of fish with an analysis pipeline for environmental DNA metabarcoding. Mol Bio\&Evo, 35: 1553-1555.

Smart AS, Weeks AR, Rooyen AR, Moore A, Mccarthy MA, Tingley R. 2016. Assessing the cost-efficiency of environmental DNA sampling. Methods Ecol Evol 7: 1291-1298.

Taberlet P, Coissac E, Hajibabaei M, Rieseberg LH. 2012. Environmental DNA. Mol Ecol 21: 1789-1793.

Takahara T, Minamoto T, Doi H. 2013. Using environmental DNA to estimate the distribution of an invasive fish species in ponds. PloS One 8: e56584

Teletchea F. 2009. Molecular identification methods of fish species: reassessment and possible applications. Rev Fish Biol Fish 19: 265.

Thomsen PF, Kielgast J, Iversen LL, Wiuf C, Rasmussen M, Gilbert MTP, Orlando L, Willerslev E. 2012. Monitoring endangered freshwater biodiversity using environmental DNA. Mol Ecol 21: 2565-2573.

Udayasuriyan R, Kalpana R. 2018. DNA Barcoding of Freshwater Prawn Species of Two Genera Macrobrachium and Caridina Using mt-COI Gene. J Gen Prot 2017.

Ward RD, Zemlak TS, Innes BH, Last PR, Hebert PD. 2005. DNA barcoding Australia's fish species. Philo Trans R Soc London B Biol Sci 360: 1847-1857.

Wilcox TM, Mckelvey KS, Young MK, Jane SF, Lowe WH, Whiteley AR, Schwartz MK. 2013. Robust detection of rare species using environmental DNA: the importance of primer specificity. PloS One 8: e59520.

Willerslev E, Hansen AJ, Binladen J, Brand TB, Gilbert MTP, Shapiro B, Bunce M, Wiuf C, Gilichinsky DA, Cooper A. 2003. Diverse plant and animal genetic records from Holocene and Pleistocene sediments. Science 300: 791-795.

Willerslev E, Hansen AJ, Poinar HN. 2004. Isolation of nucleic acids and cultures from fossil ice and permafrost. Trends Ecol Evol 19: 141147.

Yamamoto S, Masuda R, Sato Y, Sado T, Araki H, Kondoh M, Minamoto T, Miya M. 2017. Environmental DNA metabarcoding reveals local fish communities in a species-rich coastal sea. Sci Rep 7: 40368.

Zhang Y. 2015. An Introduction to Python and computer programming. An Introduction to Python and Computer Programming. Springer, Dordrecht. 